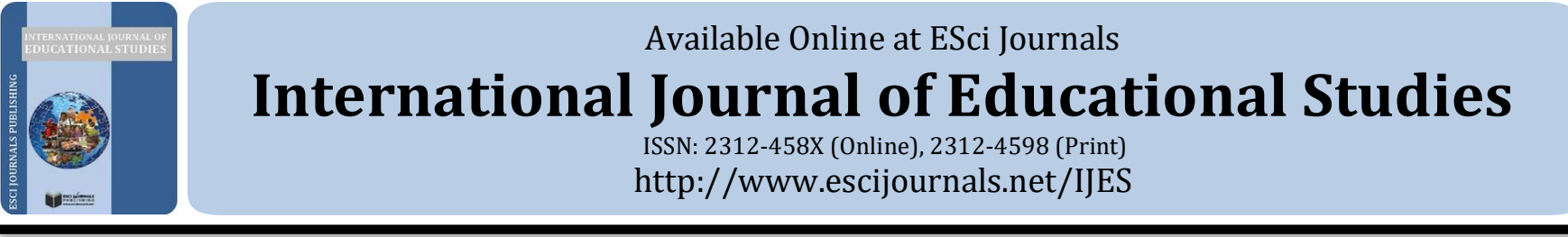

\section{AN EDUCATION SESSION ON SICKLE CELL DISEASE WITH TEACHERS IN LAGOS, NIGERIA: EVALUATION OF A RANDOMIZED CONTROLLED TRIAL}

\author{
aBolanle Ola, bAyoola Olajide, bSegun Olajide, cIain R. Williamson, dSimon M. Dyson* \\ a Department of Behavioural Medicine, Lagos State University College of Medicine (LASUCOM), 1-5 Oba Akinjobi Way, \\ G.R.A., Ikeja, P.M.B. 21266, Lagos, Nigeria. \\ b African Sickle Cell News, P. O. Box 5952, Somolu 100007, Lagos State, Nigeria. \\ c School of Applied Social Sciences, De Montfort University, Leicester, LE1 9BH UK. \\ d Unit for the Social Study of Thalassaemia and Sickle Cell, Leicester School of Allied Health Sciences, De Montfort \\ University, Leicester, LE1 9BH UK.
}

\section{A B S T RA C T}

Sickle cell disease is a major public health issue in sub-Saharan Africa, with Nigeria having the largest absolute numbers of young people living with sickle cell disease. Research in the Global North suggests that young people with sickle cell disease are not well supported at school, whilst research in the Global South focuses on attitudes to the identification of genetic carriers to prevent births of children with sickle cell disease, rather than support of those with the sickle cell disease condition itself. Between 2015 and 2017 a randomized controlled trial based on one hour education session for school teachers, based on information contained in a guide to school policy on sickle cell disease, was conducted with 402 young people with sickle cell disease across 314 schools in Lagos State, Nigeria. Young people with sickle cell disease in both intervention group and control groups showed significant decreases in the number of days of school absence and in self-reported indicators of lack of support, and significant increases in selfreported indicators of school support. The results suggest a breakdown of the randomization, probably because the young people with sickle cell disease all reacted positively to researchers taking an interest in their welfare in a context where they would usually be heavily stigmatized and would be inclined to hide their sickle cell disease status from others at school. In conclusion, conditions conducive to conducting successful research on sickle cell disease in this context - increased self-esteem in young people with sickle cell disease, reduction in within-school stigmatizing attitudes, and commitment by policy makers to improve the situation of young people in schools - are the very factors that would improve the experiences of young people living with sickle cell disease at school in Lagos, Nigeria. The fact that positive changes did occur warrants further research on this topic.

Keywords: Sickle cell disease, school health, school policy, Nigeria, randomized controlled trial.

\section{INTRODUCTION}

Sickle cell disease (SCD) is an inherited multi-system disorder that affects millions of people worldwide (Serjeant and Serjeant, 2001). Over 300,000 children with SCD are born globally each year, likely to rise to over 400,000 per year by 2050 (Piel et al, 2013). Of these, over $80 \%$ are born in Africa, mainly in West and Central Africa (Modell and Darlison, 2008).

\footnotetext{
* Corresponding Author:

Email: sdyson@dmu.ac.uk

ORCID: http://orcid.org/0000-0002-4735-2527

(C) 2018 ESci Journals Publishing. All rights reserved.
}

The World Health Organization states that "in Nigeria, by far the most populous country in the subregion, $24 \%$ of the population are carriers of the mutant gene and the prevalence of sickle-cell anaemia is about 20 per 1000 births. This means that, in Nigeria alone, about 150,000 children are born annually with sickle-cell anaemia" (World Health Organization, 2006). This makes sickle cell disease an important, but relatively neglected, public health issue in West and Central Africa (Ware, 2013). It was previously suggested that since SCD might be responsible for $5-16 \%$ of under-5 mortality in parts of sub-Saharan Africa that "greater attention to reducing 
mortality from SCD could help some African governments to achieve their targets with regard to Millennium Development Goal (MDG) number 4: to reduce their under-5 mortality rates by two-thirds during 1990-2015" (Grosse et al, 2011). Progress is possible in principle through new-born screening for SCD, where identified infants are given penicillin and malarial prophylaxis, vaccinations, and where parents are given health education advice, especially around fever and splenic sequestration (Grosse et al, 2011; Macharia et al, 2018) but a 50-90\% under-fives SCD mortality rate continues to be given as an overall estimate for sub-Saharan Africa (Grosse et al, 2011). In Nigeria people living with SCD also have to face a considerable degree of societal discrimination affecting their mental health (Ola et al, 2016).

Studies on sickle cell in schools in Nigeria have to date concentrated on knowledge of non-SCD students of their genotype (Owolabi et al, 2011); on factual information about SCD (Bazuaye and Olayemi, 2009); on attitudes of non SCD pupils to those living with SCD (Olakunle et al, 2013); on the degree to which non-SCD students hold stigmatizing attitudes towards those living with SCD (Bazuaye and Olayemi, 2009; Olakunle et al, 2013; Ola et $\mathrm{al}, 2013$ ) or else studies focus on the issue of screening and prevention (Abiola et al, 2013). The attention has therefore not been on support for the young person living with SCD themselves. Evidence from the US suggests that an intensive intervention with schools can produce short-term improvements in teacher and fellow pupil attitudes (Koontz et al, 2004).

In the UK work has examined the lack of care for young people with SCD at school, suggesting that young people are exposed to health damaging school environments (Dyson et al, 2010a), a situation not eased by teacher awareness alone (Dyson et al, 2010b). A school policy implementing changes to school procedures and environment that can operate without drawing attention to the young person with SCD as different from their peers was proposed (Dyson et al, 2010b). This resulted in the publication of a Guide to School Policy on Sickle Cell as an open education resource (CC-BY-SA). This guide contained information about SCD but also gave examples of changes at the whole school level supportive of pupils with SCD and a model individual health care plan for a student with SCD. Working with education and health colleagues from Nigeria, some of the examples of whole school changes were adapted to the situation in Nigeria.
The adaptation was then professionally translated into Yoruba, Hausa and Igbo. This project aimed to evaluate an education session for teachers in Lagos based on the guide (Nigerian English Language Version and Yoruba Language Version (Dyson et al, 2013a, b). Since SCD is stigmatized in Lagos both in general society (Ola et al, 2016) and specifically among school students (Bazuaye and Olayemi, 2009; Olakunle et al, 2013; Abiola et al, 2013) it would have been difficult to recruit students with SCD directly from schools. Many would have been adopting a strategy of not making SCD a central part of their identity (Atkin and Ahmad, 2001) and not disclosing their SCD to the school (Dyson et al, 2010b). Lagos is a metropolis of at least 16 million people characterized by high urban density and difficulties in urban travel owing to congestion. Travel of researchers to sickle cell clinics and sickle cell clubs (for recruitment of participants) and to schools (to deliver an educational session based on the sickle cell school policy) in a highly congested urban metropolis was time-consuming and expensive. In two senses then young students with SCD at school in Lagos, Nigeria represented a hard to reach population.

\section{METHODS}

Study Design and Participants: The study was a randomized controlled trial comparing the before and after effects of giving teachers information about school policy on sickle cell and providing material copies of that policy to keep. The measures assessed related to reported experiences of young people living with sickle cell disease (SCD) at school. The research was approved by De Montfort University Human Research Ethics Committee (Ref: 2015_1610) and by the Health Research and Ethics Committee of Lagos State University College of Medicine.

During the academic school year 2015-2016 four researchers, two themselves adults living with SCD, recruited young people living with SCD from three sickle cell outpatients' clinics and two sickle cell support clubs in Lagos. Eligibility criteria were: (1) aged 5-18 and attending school; (2) living with sickle cell disease (sickle cell anaemia; haemoglobin SC disease, sickle betathalassaemia or other forms of sickle cell disease, but not sickle cell trait [haemoglobin AS]); (3) who, after provision of a participant information sheet, gave assent (with parental consent), or (aged 16+) who consented, to take part. The sample was to comprise the first 400 of those eligible approached and assenting/consenting to take part, though given simultaneous recruitment by different fieldworkers, 402 young people were initially recruited. 
The intervention group comprised schools where the staff underwent a one hour educational session on sickle cell delivered by a fieldworker from the research team, a session based on information in the Guide to School Policy on Sickle Cell and provision of hard copies of that 12-page guide to the school. This intervention occurred during the 2015-2016 school year. The control group was based on prevailing standard school conditions (where an educational session was not conducted until the end of the research, after post-intervention data was collected, in the 2016-2017 school year).

All 402 participants (and/or their parents as ageappropriate) completed a baseline questionnaire during attendance at their sickle cell clinic/club. This pragmatic approach of allowing parents and young people to determine if the young person, the parent or both together should complete a questionnaire has proved workable in other circumstances (Dyson et al, 2010a). The baseline questionnaire asked about five (nonvalidated) factors increasing the challenging nature of a school environment, and five (non-validated) factors, which were taken as indicative of an overall supportive school environment. In Tables 1 and 2, the indicators are listed, together with an accompanying theoretical rationale for their use and/or references underpinning their use.

Table 1. Five Self-Reported Indicators of Lack of School Support to Students Living with SCD.

\begin{tabular}{|c|c|}
\hline Statement on Questionnaire & I have been stopped from going to the toilet when I needed to \\
\hline Rationale for Statement & $\begin{array}{l}\text { People with SCD cannot concentrate urine as readily as others and need to pass large } \\
\text { quantities of dilute urine (Dyson et al, 2010a). }\end{array}$ \\
\hline Statement on Questionnaire & I have been stopped from taking a drink of water when I needed to whilst in class \\
\hline Rationale for Statement & $\begin{array}{l}\text { People with SCD need to be well hydrated to help prevent sickle cell painful episodes } \\
\text { (Dyson et al, 2010a). }\end{array}$ \\
\hline Statement on Questionnaire & $\begin{array}{l}\text { I have been made to take physical exercise (PE) that was not suitable for someone } \\
\text { with sickle cell disease }\end{array}$ \\
\hline Rationale for Statement & $\begin{array}{l}\text { The red blood cells in someone with SCD last only } 20 \text { days as opposed to } 120 \text { days and } \\
\text { they are therefore severely anaemic (Dyson et al, 2010a). }\end{array}$ \\
\hline Statement on Questionnaire & I have been called lazy when I was tired because of my sickle cell \\
\hline Rationale for Statement & $\begin{array}{l}\text { Being severely anaemic people with SCD may be more likely to become tired and find } \\
\text { difficulty concentrating (Dyson et al, 2010a). }\end{array}$ \\
\hline Statement on Questionnaire & I have been bullied or called names at school because of my sickle cell \\
\hline Rationale for Statement & $\begin{array}{l}\text { Jaundice causing yellowing of the sclerae is one somatic sign of SCD a person may not } \\
\text { be able to hide from peers (Dyson et al, 2012). }\end{array}$ \\
\hline
\end{tabular}

Table 2. Five Self-Reported Indicators of School Support to Students Living with SCD.

\begin{tabular}{ll}
$\begin{array}{l}\text { Statement on } \\
\text { Questionnaire }\end{array}$ & $\begin{array}{l}\text { I have a written health care plan agreed between school and my family } \\
\text { The principle of having a structured written support document is derived from US } \\
\text { Department of Education (2000; 2018), UK Children and Families Act 2014 and US Centers } \\
\text { for Disease Control and Prevention Guide (2014). }\end{array}$ \\
\hline $\begin{array}{l}\text { Statement } \\
\text { Questionnaire }\end{array}$ & $\begin{array}{l}\text { I have a young person of my own age (a peer) who has been given special responsibility to } \\
\text { look out for me and help me at school }\end{array}$ \\
$\begin{array}{l}\text { Rationale for } \\
\text { Statement }\end{array}$ & $\begin{array}{l}\text { One of the key changes Nigerian educators made to the Nigerian version of the guide (Dyson } \\
\text { et al, 2013, a, b) }\end{array}$ \\
$\begin{array}{l}\text { Statement on } \\
\text { Questionnaire }\end{array}$ & $\begin{array}{l}\text { The school has ways of helping me catch up when I miss lessons } \\
\text { Rationale for } \\
\text { Statement }\end{array}$
\end{tabular}




\begin{tabular}{ll}
\hline $\begin{array}{l}\text { Statement on } \\
\text { Questionnaire }\end{array}$ & $\begin{array}{l}\text { My school has organized activities to reduce the number of mosquitoes around the school } \\
\text { One of the key changes Nigerian educators made to the Nigerian version of the guide: young } \\
\text { people with SCD are more vulnerable to death from falciparum malaria than others } \\
\text { (Williams and Obaro, 2011) }\end{array}$ \\
$\begin{array}{l}\text { Rationale for } \\
\text { Statement }\end{array}$ & I have learned about sickle cell as part of my school lessons or assemblies \\
$\begin{array}{l}\text { Questionnaire } \\
\text { Rationale for } \\
\text { Statement }\end{array}$ & Evidence from UK proposes this is one indicator of positive school ethos (Dyson et al, 2012) \\
\hline
\end{tabular}

For analysis purposes the indicators of support and lack of support were totalled to give scores between zero and five - i.e. each behaviour was deemed to have occurred or not occurred and the frequency of incidences of each indicator were not calculated. The baseline questionnaire also asked about the number of days taken off school owing to SCD-related illness in the previous 12 months. From information on school names recorded in the baseline questionnaire, schools were then randomized to intervention group and control groups. Since the intervention was orientated to the whole school (teachers having an educational session) randomization was based around the school rather than the individual student. Using an online random number table, the schools were allocated to the intervention or to the control group. Where more than one child attended the same school (no school had more than four pupils in the study with SCD) the school was allocated to the group associated with the first child listed from that school.

It was hypothesized that there would be significant differences between scores of students in the intervention and control groups on three self-reported outcomes measures post-intervention but that scores would be comparable at baseline. Students in the intervention group would report fewer days off and fewer indicators of lack of support, but higher indicators of school support at post-intervention than at baseline. Students in the control group were not expected to show any significant differences in the three measures at baseline and post-intervention.

\section{RESULTS}

402 young people (5-18 years) completed the baseline questionnaire. Of these 12 were school leavers and so would not be at school in the following academic session, and in 22 cases the name of the school was missing, so random allocation of school was not possible. This left 368 young people who attended 314 different schools
(167 intervention, 201 control group) in Lagos as the participants in the study.

The 368 participants included 167 females (45.4\%) and 199 males (54.1\%), with 2 missing values. Ages ranged from 5 to 18 years with a mean of 10.3 a median of 10 and a standard deviation of 3.5. Students attended primary school $(206,56 \%)$; junior secondary school (86, $23.4 \%)$; senior secondary school $(69,18.8 \%)$ or other types of school $(7,1.9 \%)$. The self-reported sickle cell genotype of participants were sickle cell anaemia (HbSS: 337 or 91.6\%); haemoglobin SC disease (HbSC: 13 or $3.5 \%)$, with 18 (4.9\%) missing values.

The data have been analysed using descriptive and inferential statistics. A series of three mixed $2 \times 2$ ANOVA analyses were used to assess reported differences on scores, indicating reported school days missed, indicators of school support and indicators of lack of school support between those schools who ran the intervention in the 2015-2016 school year and those who did not (a between participants factor) and at the two time periods -i.e. before and after the intervention (a within-participants factor). Means and standard deviations are reported for all pre-/post-test comparisons alongside mean difference calculations with confidence intervals at the $95 \%$ level and are presented in Table 3. To control for the increased likelihood of type one errors occurring when using multiple comparisons, significance levels were adjusted from $p \leq 0.05$ to $p \leq 0.017$ through Bonferroni correction. Effect size calculations are provided where appropriate using partial eta-squared. Assumptions around equality of variance across conditions were upheld for indicators of support and indicators of lack of support but violated for the days off outcome because of a number of outlier scores in the pre-intervention data. In line with standard practice degrees of freedom for this analysis are reported using Greenhouse-Geisser adjustment. 


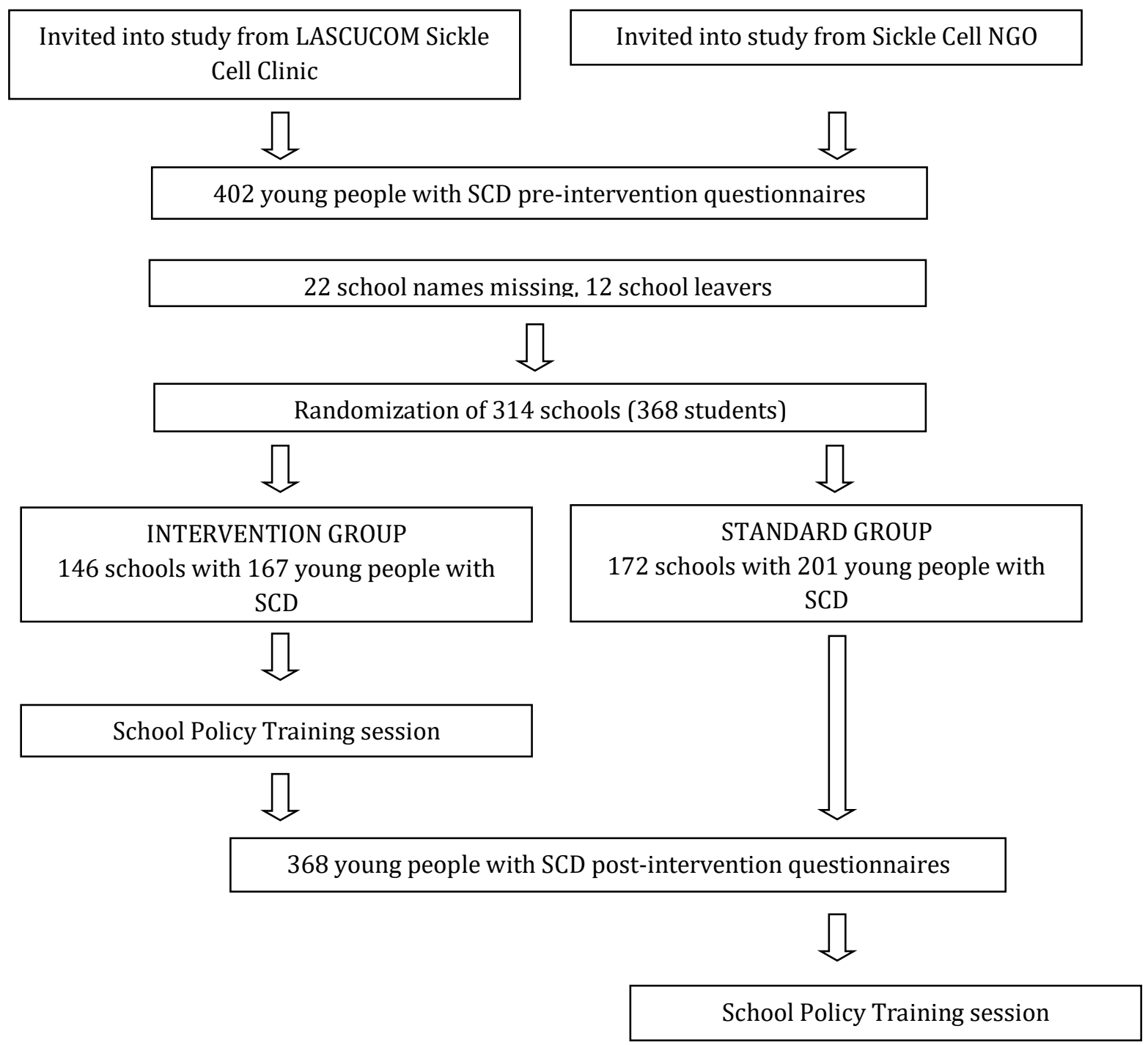

Flow chart of inclusion of school pupils with sickle cell disease (SCD) into a randomized controlled trial on teacher exposure to sickle cell school policy information.

For reported days off relating to sickle cell disease a mixed ANOVA showed no significant main effect for differences between intervention and control schools $F$ $(1.00,364.00)=0.36, p \geq 0.017$. There was a reduction in reported days off before and after the study in both sets of schools but this difference did not reach the adjusted level of statistical significance $F(1.00,364.00)=4.28$, $\mathrm{p} \geq 0.017$ ( $\mathrm{p}=0.039$ ). There was no significant interaction between the intervention-control and pre-study/poststudy factors $F(3.00,364.00)=0.47, p \geq 0.017$. The key finding here is that days missed from school related to sickle cell disease decreased in both schools who did and did not take part in the intervention. 
Table 3. Mean and standard deviation scores for the three dependent variables grouped by intervention-control and time period with mean differences.

\begin{tabular}{|c|c|c|c|c|c|c|}
\hline & $\begin{array}{l}\text { Intervention } \\
\text { Group } \\
\mathrm{N}=166\end{array}$ & $\begin{array}{l}\text { Control } \\
\text { Group } \\
\mathrm{N}=200\end{array}$ & $\begin{array}{l}\text { Intervention } \\
\text { Group } \\
\mathrm{N}=166\end{array}$ & $\begin{array}{l}\text { Control } \\
\text { Group } \\
\mathrm{N}=201\end{array}$ & $\begin{array}{l}\text { Interventio } \\
\text { n Group } \\
\mathrm{N}=166\end{array}$ & $\begin{array}{l}\text { Control } \\
\text { Group } \\
\mathrm{N}=201\end{array}$ \\
\hline & Days Off & Days Off & $\begin{array}{l}\text { Indicators of } \\
\text { Support }\end{array}$ & $\begin{array}{l}\text { Indicators of } \\
\text { Support }\end{array}$ & $\begin{array}{l}\text { Indicators } \\
\text { of Lack of } \\
\text { Support }\end{array}$ & $\begin{array}{l}\text { Indicators } \\
\text { of Lack of } \\
\text { Support }\end{array}$ \\
\hline Pre-Intervention & $\begin{array}{l}7.22 \\
(S D=15.43)\end{array}$ & $\begin{array}{l}8.28 \\
(S D=21.84)\end{array}$ & $\begin{array}{l}1.67 \\
(S D=1.32)\end{array}$ & $\begin{array}{l}1.47 \\
(S D=1.28)\end{array}$ & $\begin{array}{l}1.01 \\
(S D=1.23)\end{array}$ & $\begin{array}{l}0.97 \\
(S D=1.19)\end{array}$ \\
\hline Post-Intervention & $\begin{array}{l}3.87 \\
(S D=5.87)\end{array}$ & $\begin{array}{l}3.80 \\
(S D=4.48)\end{array}$ & $\begin{array}{l}1.92 \\
(S D=0.92)\end{array}$ & $\begin{array}{l}1.69 \\
(S D=0.88)\end{array}$ & $\begin{array}{l}0.25 \\
(S D=0.61)\end{array}$ & $\begin{array}{l}0.06 \\
(S D=0.24)\end{array}$ \\
\hline $\begin{array}{l}\text { Mean Differences } \\
\text { with 95\% Confidence } \\
\text { Intervals }\end{array}$ & $\begin{array}{l}3.35 \\
(\mathrm{CI}: 1.12- \\
5.64)\end{array}$ & $\begin{array}{l}4.48 \text { (CI:1.09 } \\
-9.00)\end{array}$ & $\begin{array}{l}0.25 \text { (CI: } \\
0.08-0.49 \text { ) }\end{array}$ & $\begin{array}{l}0.22 \text { (CI: } 003 \\
-0.42 \text { ) }\end{array}$ & $\begin{array}{l}0.76 \text { (CI: } \\
0.55-0.95)\end{array}$ & $\begin{array}{l}0.91 \text { (CI: } \\
0.74-1.07 \text { ) }\end{array}$ \\
\hline
\end{tabular}

Where numbers are less than 167 or 201 this indicates missing data.

For indicators of support, a mixed ANOVA showed a large significant main effect between intervention and control schools $F(1,365)=5.96, p \leq 0,17, \eta^{p 2}=0.16$. There was also a significant large main effect for differences in responses before and after the study $F(1,365)=9.10$, $p \leq 0.017, \eta^{p 2}=0.24$. There was no significant interaction between intervention-control and pre-study/post-study factors $F(3,365)=0.33, p \geq 0.017$. This shows that indicators of support were significantly higher in the schools allocated to the intervention, both before and after the intervention, and also that there were significant increases in both types of schools after the study. See Figure 1, below:

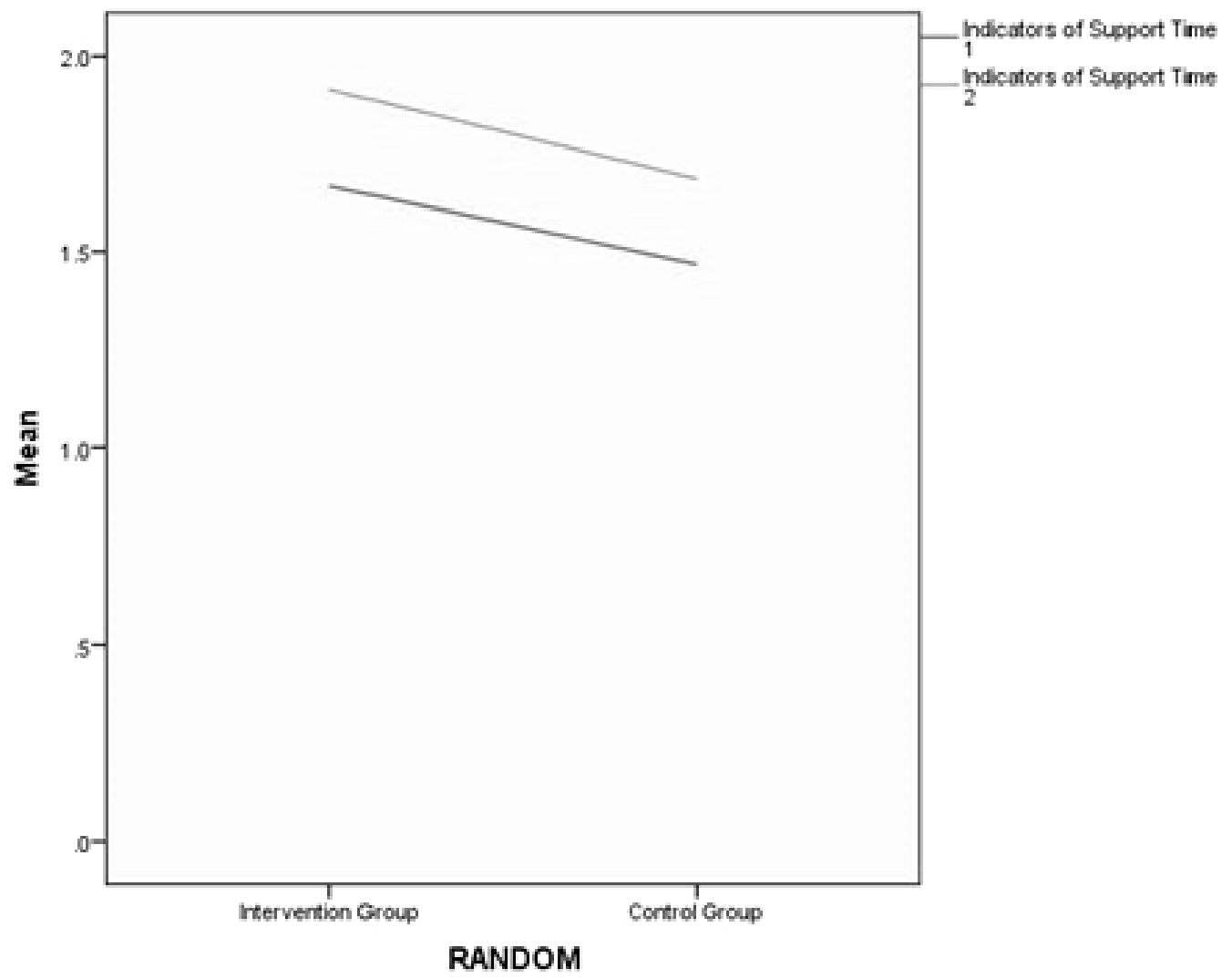

Figure 1. Mean differences in indicators of support in intervention and control schools. 
For indicators of lack of support, a mixed ANOVA showed no main effect for differences between intervention and control schools $F(1,365)=2.86, p \geq 0,17$. There was a significant and large main effect for testing before and after the study $F(1,365)=159.56, p \leq 0.017, \eta^{p 2}=0.30$. There was no significant interaction between intervention-control and pre-study/post-study factors $F(3,365)=1.35, p \geq 0.017$. This shows that the significant decrease in indicators of lack of support did not differ between schools randomly allocated to the intervention and control groups. See Figure 2 below:

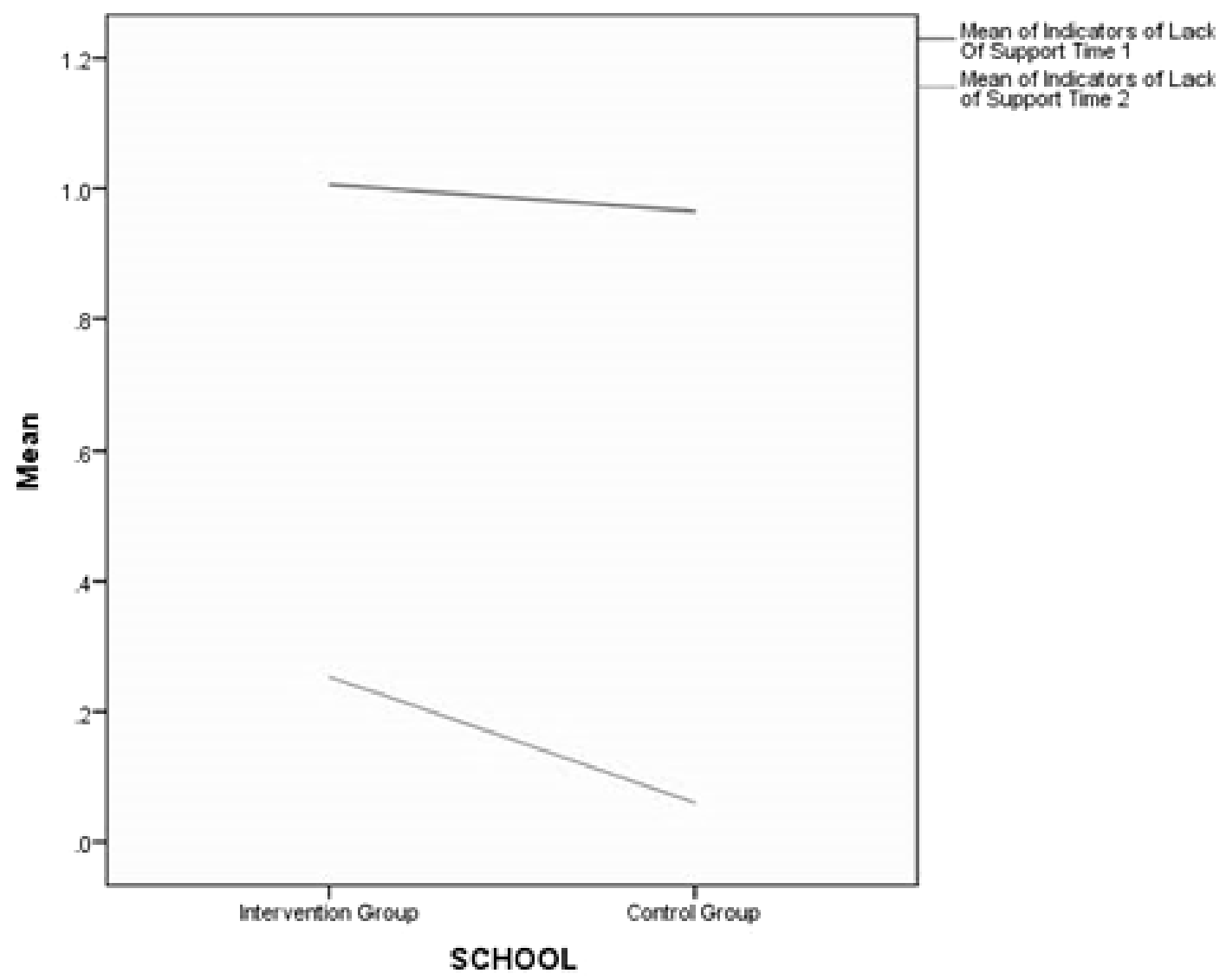

Figure 2. Mean differences in indicators of lack of support in intervention and control schools.

\section{DISCUSSION}

It is striking that the extant literature on sickle cell in schools in Nigeria is almost entirely geared towards knowledge of genetics, the attitudes of those without SCD, and on knowledge and attitudes towards preventing births through sickle cell screening. The idea that a research-based initiative might be geared towards improving the school experiences of those living with $S C D$, is therefore remarkable, perhaps unique, when considered in social context. The idea that someone cared about them and their education was, therefore, likely to be a novel experience for many students living with SCD in Lagos.
An initial limitation concerns the nature of the intervention. Although the education session for teachers was based on information in the Guide to School Policy on Sickle Cell, this was not an intervention based on the formal adoption and formal implementation by the school of the school policy, backed by those with power such as head teachers, school governors or by the Lagos State Basic Education Board. Since a major discourse surrounding pupils with SCD in Nigeria is that they do not live long and that the family is wasting money in investing in the education of a child with SCD, considerable political will contrary to popular (stigmatizing) public opinion would have to be 
mobilized to enable such an investment by education leaders. A further limitation was that no data were collected on the breakdown of recruitment origins between sickle cell clinics and clubs.

A major limitation to the study was signalled by the lack of any significant changes between the control and intervention groups, coupled with very strong before and after-effects in both groups, suggesting that random allocation had been undermined. It had not been felt possible to recruit through schools themselves, since the evidence is that, even in countries with less societal stigma, at least one third of pupils with SCD prefer not to disclose their SCD identity (Dyson et al, 2010a) and with greater levels of societal stigma in Nigeria, the tendency towards non-disclosure would likely have been even greater. Requesting the information of the school (and schools requesting the information of their students in ways we would not have been able to control), would have raised serious ethical issues of "outing" young people with SCD who wished to remain anonymous. Recruiting through sickle cell clinics and clubs had the advantage of potentially allowing the young people to remain anonymous within the school setting even whilst participating in the study. However, such recruitment probably explains a breakdown of the effects of randomization, as both sickle cell clinics, where waiting times are long, and social support clubs enabled young people with SCD ample opportunity to discuss their participation in the study with one another, sometimes in both settings. As permission to work with statefunded schools was not given, and/or the schools approached demanded money for participation, participating schools were private, fee-paying schools, with reportedly stronger parent-teacher associations than in the public sector, and researchers reported a desire on the part of teachers for more information on SCD, suggesting that many teachers in the control group may have been motivated to seek further information on SCD. A further limitation was the distribution of young people across different schools. We had modelled a $1 \%$ prevalence for SCD in the 5-18 age group and had estimated that 400 young people with SCD would be distributed across approximately 100 schools. In the event when it became apparent that they attended 314 different schools, additional funding was sought and granted to enable the fieldworkers to complete the study. Moreover, regular heavy traffic congestion made visiting so many schools a slow and laborious process and the young people with SCD, therefore, comprised a hard-to-reach population in two senses: they may not have wished their identity to be known at school and travel to schools by fieldworkers was extremely timeconsuming.

Although the results did not indicate any significant differences between control and intervention groups, the results of before-and-after comparisons were very highly significant, with improvements in reducing reported unsupportive behaviours on the part of school staff, improving positive school activities and greatly reducing numbers of days off owing to SCD-related illness. The latter is important because it suggests that social factors and not only the illness itself may have an important effect on school attendance.

The explanation we would propose for the results builds on the work in UK schools, where school ethos has been proposed as a social explanation of overall pupil achievement in schools (Banerjee et al, 2014) and a possible explanation of improved school experience for young people living with SCD (Dyson et al, 2012). It seems plausible that, irrespective of allocation to control/intervention groups, that young people with SCD would be sensitized to being part of research on an illness, an illness they would be more used to experiencing as a negative or something to hide in the majority of settings (including their own neighbourhoods). The research appears to have prompted something akin to a Hawthorne effect, whereby participation, and being paid attention to as special, galvanized the young people. This may have been further reinforced by the presence of fieldworkers, themselves living with SCD, who therefore modelled both survival into mature adulthood, which has been shown elsewhere in Africa to have positive effects challenging negative discourses around sickle cell (Dennis-Antwi et al, 2011) and the positive role model of being engaged in productive research work.

A further limitation concerns the nature of the intervention. A situation where teachers reported knowing that a pupil had SCD was not associated with a reduction in a poor school environment in the UK (Dyson et al, 2010b). This limitation suggests that any study seeking to examine the effects of school environment on students with SCD would need to recruit participants from the schools themselves. Recruitment from a wide range of schools of SCD pupils in sufficient numbers would require that pupils with SCD 
were not widely discriminated against in the society or at school as they currently are (Abiola et al, 2013; Owolabi et al, 2013), and that policy makers were committed not primarily to increasing knowledge of genotype to try to reduce births of children with SCD (itself a social policy liable to have a negative impact on self-esteem of those living with SCD) but to supporting those living with SCD in schools. Thus, the very conditions that would improve the prospects of conducting successful research - increased self-esteem in young people with SCD, reduction in within-school stigmatizing attitudes, and commitment by policymakers to improve the situation of young people in schools - are the very factors that would improve the experiences of young people living with SCD at school in Lagos, Nigeria. In conclusion, further research based on the implementation of a school policy on sickle cell backed by the appropriate Education Board would seem warranted.

\section{ACKNOWLEDGEMENTS}

The research was funded through the UK Higher Education Innovation Fund (HEIF). We would like to thank all the young people, their parents and the sickle cell clubs and clinics of Lagos State, Nigeria for their participation.

\section{REFERENCES}

Abiola, A. O., Ojika, B. O., Mannir, B., Abba, S. K., Muhammad, M., Ibrahim, M. T. and Akanmu, S. S. (2013). Effect of health education on the knowledge and attitude to sickle cell disorder and screening practices among school of nursing students in Sokoto, Nigeria. Nigerian Quarterly Journal of Hospital Medicine, 23(1), 65-68. https://europepmc.org/abstract/med/24579498

Atkin, K. and Ahmad, W. I.U. (2001). Living a 'normal' life: young people coping with thalassaemia major or sickle cell disorder. Social Science and Medicine, 53(5), 615-626. https://doi.org/10.1016/S02779536(00)00364-6

Banerjee, R., Weare, K. and Farr, W. (2014). Working with 'Social and Emotional Aspects of Learning' (SEAL): Associations with school ethos, pupil social experiences, attendance, and attainment. British Educational Research Journal, 40(4), 718742. https://doi.org/10.1002/berj.3114

Bazuaye, G. N. and Olayemi, E. E. (2009). Knowledge and attitude of senior secondary school students in Benin City Nigeria to Sickle Cell Disease. World
Journal of Medical Sciences, 4(1), 46-49. https://pdfs.semanticscholar.org/6b37/568d43f3 18f0ee8ebf8a9b9d34e314f923ec.pdf

Centers for Disease Control and Prevention (2014) Tips for Supporting Students with Sickle Cell Disease Retrieved from:

https://www.cdc.gov/ncbddd/sicklecell/docume nts/tipsheet_supporting_students_with_scd.pdf

Dennis-Antwi, J. A., Culley, L., Hiles, D. R. and Dyson, S. M. (2011). 'I can die today, I can die tomorrow': lay perceptions of sickle cell disease in Kumasi, Ghana at a point of transition. Ethnicity and Health, 16(45), 465-481.

https://doi.org/10.1080/13557858.2010.531249

Dyson, S. E., Atkin, K., Culley, L., Demaine, J. and Dyson, S. M. (2012). School ethos and variation in health experience of young people with sickle cell disorder at school. Diversity and Equality in Health and Care, 9(1), 33-44.

http://diversityhealthcare.imedpub.com/schoolethos-and-variation-in-health-experience-ofyoung-people-with-sickle-cell-disorder-atschool.php?aid $=1828$

Dyson, S. M., Abuateya, H., Atkin, K., Culley, L., Dyson, S. E., Rowley, D. and members of the Sickle Cell and Education (SCED) Group. (2010a). Reported school experiences of young people living with sickle cell disorder in England. British Educational Research Journal, 36(1), 125-142. https://doi.org/10.1080/01411920902878941

Dyson, S. M., Atkin, K., Culley, L. A., Dyson, S. E., Evans, H. and Rowley, D. T. (2010b). Disclosure and sickle cell disorder: a mixed methods study of the young person with sickle cell at school. Social Science and Medicine, 70(12), 2036-2044.

https://doi.org/10.1016/j.socscimed.2010.03.010

Dyson, S.M., Ojo, B., Maiguwa, N., Lah, J., Inusa, B., Anionwu, E.N. and Okolo, C. (2013a) Guide to School Policy on Sickle Cell Nigerian Yoruba Language Version Retrieved from: http://sicklecellanaemia.org/policy/sickle-cellschools-guide-yoruba-translation/

Dyson, S.M., Ojo, B., Maiguwa, N., Lah, J., Inusa, B., Anionwu, E.N. and Okolo, C. (2013b) Guide to School Policy on Sickle Cell Nigerian English Language Version Retrieved from:

http://sicklecellanaemia.org/policy/sickle-cell-schoolsguide-nigerian-english-translation/ 
Grosse, S. D., Odame, I., Atrash, H. K., Amendah, D. D., Piel, F. B. and Williams, T. N. (2011). Sickle cell disease in Africa: a neglected cause of early childhood mortality. American Journal of Preventive Medicine, 41(6), S398-S405. https://doi.org/10.1016/j.amepre.2011.09.013

Koontz, K., Short, A. D., Kalinyak, K. and Noll, R. B. (2004). A randomized, controlled pilot trial of a school intervention for children with sickle cell anemia. Journal of Pediatric Psychology, 29(1), 717. https://doi.org/10.1093/ipepsy/jsh002

Macharia, A. W., Mochamah, G., Uyoga, S., Ndila, C. M., Nyutu, G., Makale, J. and Awuondo, K. O. (2018). The clinical epidemiology of sickle cell anemia in Africa. American Journal of Hematology, 93(3), 363-370. https://doi.org/10.1002/ajh.24986

Modell, B., and Darlison, M. (2008). Global epidemiology of haemoglobin disorders and derived service indicators. Bulletin of the World Health Organization, 86, 480-487.

https://www.scielosp.org/scielo.php?pid=S004296862008000600017\&script=sci arttext\&tlng=en

Ola, B.A., Coker, R. and Ani, C. (2013). Stigmatising attitudes towards peers with sickle cell disease among secondary school students in Nigeria. International Journal of Child, Youth and Family Studies, 4(4), 391-402. https://doi.org/10.18357/ijcyfs44201312693

Ola, B. A., Yates, S. J. and Dyson, S. M. (2016). Living with sickle cell disease and depression in Lagos, Nigeria: A mixed methods study. Social Science and Medicine, 161, 27-36.

https://doi.org/10.1016/j.socscimed.2016.05.029

Olakunle, O. S., Kenneth, E., Olakekan, A. W. and Adenike, O. B. (2013). Knowledge and attitude of secondary school students in Jos, Nigeria on sickle cell disease. Pan African Medical Journal, 15(1) https://doi.org/10.11604/pamj.2013.15.127.2712

Owolabi, R. S., Alabi, P., Olusoji, D., Ajayi, S., Otu, T. and Ogundiran, A. (2011). Knowledge and attitudes of secondary school students in Federal Capital
Territory (FCT), Abuja, Nigeria towards sickle cell disease. Nigerian Journal of Medicine: Journal of the National Association of Resident Doctors of Nigeria, 20(4), 479-485.

https://www.ajol.info/index.php/njm/article/vie $\underline{w} / 91673$

Piel, F. B., Hay, S. I., Gupta, S., Weatherall, D. J. and Williams, T. N. (2013). Global burden of sickle cell anaemia in children under five, 2010-2050: modelling based on demographics, excess mortality, and interventions. PLoS medicine, 10(7), e1001484.

https://doi.org/10.1371/journal.pmed.1001484

Serjeant, G.R. and Sergeant, B.E. (2001).Sickle Cell Disease $3^{\text {rd }}$ Edn. Oxford: Oxford University Press. https://global.oup.com/academic/product/sicklecell-disease-9780192630360?lang $=\mathrm{en} \& \mathrm{cc}=\mathrm{sa}$

UK Department for Education Children and Families Act 2014 Retrieved from: http://www.legislation.gov.uk/ukpga/2014/6/pd fs/ukpga 20140006 en.pdf

US Department of Education (2000) Individual Education Plans Retrieved from:

http://ed.gov/parents/needs/speced/iepguide/index.ht $\mathrm{ml}$

US Department of Education (2018) 504 Plans Retrieved from:

http://www2.ed.gov/about/offices/list/ocr/504faq.html

Ware, R. E. (2013). Is sickle cell anemia a neglected tropical disease?. PLoS neglected tropical diseases, $7(5), \mathrm{e} 2120$. https://doi.org/10.1371/journal.pntd.0002120

Williams, T. N. and Obaro, S. K. (2011). Sickle cell disease and malaria morbidity: a tale with two tails. Trends in Parasitology, 27(7), 315-320. https://doi.org/10.1016/j.pt.2011.02.004

World Health Organization (2006). Sickle Cell Anaemia Report of the 59th World Health Assembly (2006) Retrieved from: http://apps.who.int/gb/archive/pdf files/WHA59 $\angle$ A59 9-en.pdf 